\title{
СИНТЕЗ НОВЫХ ПЕПТИДОМИМЕТИКОВ НА ОСНОВЕ ПРОИЗВОДНЫХ ПРИРОДНЫХ АМИНОКИСЛОТ В КАЧЕСТВЕ АНТИБАКТЕРИАЛЬНЫХ АГЕНТОВ
}

\section{М.С. Стяжкина, О.А. Петракова, Т.Г. Бодрова, Ю.Л. Себякин}

МИРЭА - Российский технологический университет, институт тонких химических технологий им. М.В. Ломоносова, 119571, ЦФО,г. Москва,просп. Вернадского, 86.

DOI: 10.19163/MedChemRussia2021-2021-511

E-mail: c-221@yandex.ru

Рост бактериальной резистентности к природным антибиотикам стал одной из главных проблем современной медицины. Многие фармацевтические компании активно занимаются поиском альтернативных стратегий разработки действующих препаратов. Антимикробные пептиды рассматриваются как многообещающие агенты, сочетающие в себе эффективность и безопасность[1]. Нами предложена схема синтеза ряда катионных амфифиловна основе додецилтриптамина с разветвляющим звеном в виде остатков L-лизина или L-орнитина и производными Gly, $\beta$-Ala или GABA в полярном блоке.<smiles>[R]NCCCC(N[R])C(=O)N(CCCCCC)CCc1c[nH]c2ccccc12</smiles><smiles>[R]NCCCC[C@H](N[R])C(=O)N(CCCCCC)CCc1c[nH]c2ccccc12</smiles>

$\mathbf{R}=$ Gly, $\beta-$ Ala, GABA

Схема 1.

Преимущество реализованной схемызаключается в простоте и универсальности. Предварительная проверкаактивностив отношении грамположительных бактерий Bacillussubtilis и грамотрицательных бактерий Escherichiacoli показала удовлетворительные результаты со значениями МИК 2-4 мкг/мл.

Работа поддержана грантом Российского фонда фундаментальныхисследований, проект РФФИ №20-04-00672.

\section{Литература}

[1] Lachowiczletal. The Best Peptidomimetic Strategies to Undercover Antibacterial Peptides // International Journal of Molecular Sciences. - 2020. - T. 21. - №. 19. - C. 7349. 